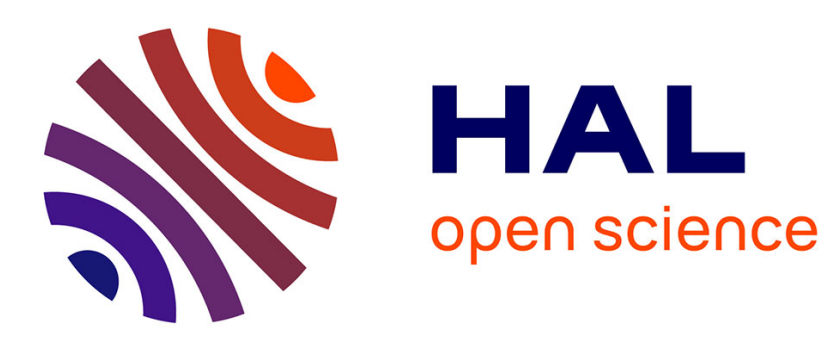

\title{
Sociology of sports organizations. A general perspective, limits and views in France
}

\author{
Bernardeau-Moreau Denis
}

\section{To cite this version:}

Bernardeau-Moreau Denis. Sociology of sports organizations. A general perspective, limits and views in France. Sport in Society, 2019. hal-03270485

\section{HAL Id: hal-03270485 \\ https://hal.science/hal-03270485}

Submitted on 30 Jun 2021

HAL is a multi-disciplinary open access archive for the deposit and dissemination of scientific research documents, whether they are published or not. The documents may come from teaching and research institutions in France or abroad, or from public or private research centers.
L'archive ouverte pluridisciplinaire HAL, est destinée au dépôt et à la diffusion de documents scientifiques de niveau recherche, publiés ou non, émanant des établissements d'enseignement et de recherche français ou étrangers, des laboratoires publics ou privés. 


\section{Title Sociology of sports organizations}

Subtitle A general perspective, limits and views in France

Bernardeau-Moreau Denis ${ }^{1}$

Abstract

This article intends to take stock of the sociology of sports organizations in France since the first works that appeared on the subject in the 1980s. Although its development coincides with the professionalization of a sector that had long been state-run and institutionalized, three axes of development can be identified that are focused on interest groups, governance, and configurations. This paper will then discuss the operational limits of this discipline and give its prospects for development.

Key words: sociology of organizations, professionalization of sport, typology of sports organizations, interest groups, sport governance, operational limits.

\section{Introduction}

In France, the sociology of sports organizations has existed as a discipline for around 40 years. It is relatively new compared to other branches of sociology, notably the sociology of organizations, the origins of which date back to the pioneering works of Frederick Winslow Taylor (1911) and Max Weber (1965) at the end of the $19^{\text {th }}$ century. This development coincides with the professionalization of a sector that had long been very institutionalized and state-run (Gasparini 2000). This field of sociology was established over several successive stages as the major theories of the sociology of organizations appeared (Lafaye 1996), including the standard principles developed in France that Erhard Friedberg named the French school of the sociology of organizations (Friedberg 1993). Cited among these works are the strategic analysis of Michel Crozier and Erhard Friedberg (1977), the identity approach of Renaud Sainsaulieu (1987), the reasoning of honor by Philippe d'Iribane (1989), the theory of conventions by Luc Boltanski and Laurent Thévenot (1991), the theory of the logic of action by Henri Amblard et al. (1996), the theory of social regulation by Jean-Daniel Reynaud (19971999), and also the actor-network theory by Madeleine Akrich, Michel Callon and Bruno Latour (2006). All these works have rightly found a particular resonance in the field of sports organizations (Gasparini 2003; Bernardeau-Moreau 2004; Barget and Vailleau 2008), including the changes in recent decades that characterize this "third era" mentioned by Jean-Paul Callède (1988). Although sport sociology as an academic discipline was first seen at the end of the $19^{\text {th }}$ century (Callède 2007), real momentum occurred in the 1960s, which translated into individualized research topics (Callède 2010) with authors such as Joffre Dumazedier (1962), George Magnane (1964), Jean Meynaud (1966) and Michel Bouet (1968). In the following years, quantitative data on French practices has grown considerably, supplemented by the arrival of various influences - Bourdieusian (Gasparini 1996; Pociello 1999), Boudonian (Mayaux 1996;

\footnotetext{
${ }^{1}$ Univ. Artois, Univ. Lille, Univ. Littoral Côte d'Opale, ULR 7369, Unité de Recherche Pluridisciplinaire Sport Santé Société (URePSSS), F-62800 Liévin, France.
} 
Chifflet 1987), and even Marxist (Brohm 1976). In the 1980s, the studies started to look at the logical sequences of interest and democratic dysfunction in sports organizations (Yerles 1984; Malenfant 1988). Initially based on the relationships between volunteers and employees and non-profit, especially federal organizations, it was at the end of the 1990s that works on professionalization in sport appeared with a focus on both sociology and management (Moingeon 1991; Loret 1995; Bayle 1999). At the start of the 2000s, the permanent bases made it possible to enduringly establish the sociology of sports organizations in the seemingly established French scientific community, justifying the publication of a piece of work that was entirely dedicated to the subject (Gasparini 2000). Between the sociology of work and occupations on one side and management sciences on the other, the sociology of sports organizations has gradually established itself in the field of sports sciences, even if its rate of development remains limited. After 40 years of existence, a review of knowledge produced in this field would therefore be useful, even if it is not easy to do as the scientific and thematic domains appear to often be intertwined. Combining sociological approaches with historic, economic, administrative, and managerial approaches to organizations, as well as federal interest groups, non-profit groups, public or commercial institutions, the sociology of sports organizations continues to struggle to delineate its scientific field ${ }^{2}$. However, its uniqueness is the guarantee of its legitimacy and justifies our endeavors to define its parameters as precisely as possible. Since the eponymous work by William Gasparini cited above, rare are the publications that suggest an overview of works and research in sociology of sports organizations. The aim of this article is to fill this gap and open the debate on the contributions of this branch of sociology and on its limitations and its future prospects.

The 1980s marked the starting point from which, as explained by Eric Barget and Daniel Vailleau (2008, 80), two sources fueled theories of sports organizations: a management source in the publication by Alain Loret (1995) on sport and management and a sociological source in the publication by Bernard Ramanantsoa and Catherine Thiéry-Baslé (1989) on sports federations. Alain Loret's ambition was two-fold. It was a question of defining the emerging concept of sports management and designing its content. It was also a case of recognizing the statement of a professionalization process that brings in "a new range of skills" (Loret 1995, 16) calling on managerial methods and resources that increasingly come from the private, commercial sector. From a sociological perspective, Bernard Ramanantsoa and Catherine Thiéry-Baslé analyze the relatively unknown sector of sports federations, with each one constituting an "organized company with its organizational charts and its many and complex rules of operation" (Ramanantsoa and Thiéry-Baslé 1989, 126). The authors explain that sports federations have hitherto been considered as "places rather than structures" (Ramanantsoa and Thiéry-Baslé 1989, 14), making them subject to challenges, especially of an economic nature, that cause them to gradually transition into a "new state of social relations [via] the search for another suitable mode of collective action, both in terms of management and association" (Ramanantsoa and Thiéry-Baslé 1989, 16). Several explanatory causes have been identified. The hybridization of modes of

\footnotetext{
${ }^{2}$ We can note that this difficulty in positioning oneself in a field that crosses problems of a pluralism of scientific disciplines and postures, concerns the whole of the sociology of organizations [see Balle 1990]. We will come back later.
} 
collective action and competition between public and private structures, added to which is a growing demand for new skills, make up the characteristic factors of increasing professionalization that the following works will corroborate.

Boosted by the works of these researchers, the sociology of sports organizations will subsequently develop along three subject axes. On one side, a sociology of interest groups will appear that is mindful of the relations of powers and transformations in types of organization between volunteers and employees. On the other side, the redistribution of this map of powers may favor a more political approach that focuses on types of governance and political strategies implemented by public and private actors to stabilize this new state of social relationships. Ultimately, from a more macrosociological and evolutionist angle, we find the organizational configurations that open up, with contingency theories, a field of investigation conducive to modelling of life cycles and steps in sports organizations to adjust to a changing environment. By addressing these three approaches, our aim is to summarize the principal works that will attempt to analyze federal, non-profit, state, regional, and entrepreneurial sports organizations using the main sociological theories of organizations. In short, our goal is to uncover points of agreement that are likely to give an overall logical sequence of the results obtained, and also to demonstrate the limitations of these pieces of research and the means of reducing these. All the works referenced in this article have been created from several bibliographic databases, including research platforms Cairn, Revue.org and Persée.

This article includes four parts. The first three parts are focused on a situational analysis and a critical assessment of research conducted on the sociology of sports organizations. From the pioneering works carried out in the 1980 s, it can be seen that three major orientations took shape that focus on interest groups and the relationships of authorities on typology and governance and, lastly, on configurations and life cycles. The organizations studied were public and private, non-profit, federal, state, regional, and entrepreneurial. The fourth part is a reflection on the limitations and prospects for the development of the sociology of sports organizations. We deal progressively with its operational impact via a more interventionist approach. To conclude, we raise the need for the sociology of sports organizations to reconcile the priorities of a science and a practice to fulfill the fundamental aim of increasing its visibility in the eyes of researchers and actors in direct contact with the changing world of sport.

\section{A sociology of interest groups: amateurs vs. professionals}

In the 1980s, researchers started to become interested in the strategies of non-profit actors. Therefore, the research projects focused on interest groups that were seen as pressure groups that bring together individuals who share common interests (Offerlé 1998, 44). There are many such interest groups in sports (Ringuet-Riot 2014; Gasparini 2003) and they are becoming more and more active. Economic, sports, professional, and political lobbies are supported by paid managers who are angling for strategic positions, volunteer managers who are defending their turf at the head of major federations, and public powers who are acting in the name of public service and national interest. In national bodies of federal organizations, the studies focused on the nature of relationships that involve, in particular, elected volunteers and their employees against a 
backdrop of professionalization. Magdeleine Yerles (1984) studied the strategies and motivations of the two groups of managers (elected officials and technical experts) in two French tennis and volleyball federations and two such Quebecois federations. In addition, the author shows that federations are not inflexible and that the strategies developed by the groups of actors often fuel opposition between groups with differing interests. The researchers gradually assess the effects of professionalization that, although in its infancy in the majority of sports organizations, is capable of creating long-term change in the internal power dynamics between volunteers and employees and between amateurs and professionals. Inspired by the works of Michel Crozier and Erhard Friedberg (1977) and Philippe Bernoux (1985) on the sociology of organizations, Pierre Chifflet (1987, 287-297) analyzed the interplay of powers in sports federations and their operating logic. He defined three types of organizational culture: the voluntary culture of elected parties based on a federal mindset, the culture of public service of operating frameworks provided by the state, and the managerial culture of performance and profitability by managers and experts. The author notes that in the discourse of federal managers, these three types of cultures appear, although it is the latter that poses the most problems because it favors performance and professionalization. In this fight for wins and territory, Charles Suaud (1996) observes that power tends to be monopolized by a leading social group that invests in management positions "from which it is possible to take specific actions on the routes to take in practice and to impose sporting values and meanings that conform to their ethos of order" (Suaud 1996, 30). In the conflicts that can break out between the managers, Pascal Chantelat (2001) saw the confrontation of two cultures: that of the amateur, at once traditional and based on selflessness, and the managerial approach of the new managers. Over the course of this research into tennis and equestrian sports federations, Denis Bernardeau-Moreau (2004) noted a type of professionalization in the work of major organizations, that of volunteer managers whose proven skills - the author refers to "professional volunteers" - tend to keep out the most amateur volunteers. The researchers quickly widened their scope of research to include other interest groups, such as those that develop within local associations and also in public institutions and sports initiatives. The relationships of authorities and the power dynamics between volunteer managers and employees in large federations all exist in local organizations as well (even if they are often more subdued and diffuse). Here, tensions are also often generated by streamlining the implementation of work processes, which puts into question the future of the voluntary work. For Chantal Malenfant (1988), the new forms of work undertaken by employees in sports organizations indicate the appearance of a new, more professional type of volunteer that is renewing the forms of sociability in sports. Remy Viallon and Pascal Chantelat (2001), who analyzed the entrepreneurial operation of Grenoble University Club (GUC), explain that these new modes of working combine the specialization of tasks, divisional structuring, diversifying sources of finance, and rationalizing skills needs. In his analysis of athletic clubs, Jacques Ion (2001) also noted an opposition between the club logic of a strong feeling of local belonging and a logic of maximum yield that requires the use of specialized skills. Gildas Loirand (2001) refers to the "fundamental paradox" between the demands of rationalization to which sports organization service providers must respond and the need to preserve their identity, which is traditionally based on the logic of volunteerism, selflessness, and lack of cost. In accordance with a more Bourdieusian approach, William Gasparini and Sébastien Stumpp (2003) published their research on volleyball 
clubs and described the identity strategies that structure the space of social positions between those who support and oppose professionalization. However, although the professionalization of associations has multiple consequences, both organizational and structural, Emmanuelle Walter and Marc Falcoz (2007) worked to show that it does not erase the original identity of giving and selflessness taken on by the volunteers. Although put under stress by professionalization and increased employee skills, the authors explain that volunteer work will not disappear and will continue to remain the bedrock on which the non-profit organization's identity is built. Relationships have also changed in municipalities. Jean-Paul Callède (1988) was engaged in a sociological analysis of the municipal organization of sports phenomena. Inspired by the strategic analysis of Michel Crozier and Erhard Friedberg and the inductive posture of the different situations that she considered, Nadine Noé (1989) studied the interplay between actors in the municipalization of sports in a Parisian municipality, while JeanPierre Mounet and Pierre Chifflet (1993) tried to define the "specific system of action" in an inter-community sports organization by demonstrating the power dynamics between local elected officials, non-profit volunteers, and managers who were all involved with the building of an aquatic center. We can also cite the works of William Gasparini and Luc Scheeck (1999), who describe how services are faced with the need for organizational change when new municipal policy is launched. Referring to JeanDaniel Reynaud's theory of social regulation (1997), they show that autonomous rules sometimes complete formal rules of control and sometimes make it possible to twist them to the interest of the actors working for their group and also for their own personal benefit when they carry out shifts in local sports clubs. Nor is the company any longer exempt from the logical sequences of interests that combine and confront each other. As part of a study focusing on a management company with a public service delegation contract, Cédric Richet and Bastien Soule (2007) analyzed the interplay of opposition and influence that is mobilized by lifeguards to sway their management. The authors, by referring to the strategic analysis, described in short the positions of actors and employees in sports, who are also "calculating beings [...] at the root of individual and collective actions" (Richet and Soulé 2007, 21). In the same professional industry, Denis Bernardeau-Moreau, François Grima and Pascal Paillé (2012), enlisting the works on the conventions of Luc Boltanski and Laurent Thévenot (1991), analyzed the types of compromise and arrangements suggested by private managers in charge of public swimming pools. The authors analyzed how, in crisis situations, managers try to arrive at a compromise with their employees based on the principle of a commercial public service, this common good that makes it possible to bring together the commercial world of the private sector and the civil world of the public sector.

In trying to take into account the developments and changes that sports organizations undergo, the researchers applied theories of the sociology of organizations, particularly strategic analysis, the theory of social regulation and convention theory. Their investigations have led them to identify recurring explanatory elements. Power plays and challenges for territory, however contentious they are, bring social groups with different cultures, strategies, and interests into conflict. Ultimately, it appears quite clear that all of these works come to coinciding conclusions on employees and professionals taking power from volunteers and amateurs. The process of professionalization in the work is presented as a pervasive logical sequence of rationalization and skills, which tend to remove the least-prepared actors from positions where they have power and 
create political games. This inversion of the power dynamics between volunteers and employees, amateurs and professionals also contributes to disrupting the balance of the interplay between actors. However, in this scientific field where social sciences and management sciences mix and sometimes blend, there may be a lack of unifying vision required to better consider this fragmentation of sports organizations and this questioning of how the power balance is set out within sport, beyond each situation related by researchers. In order to try and remedy this, some researchers suggest typologies that make it possible to better re-establish internal logics in organizations and actors who create them. Other pieces of work also address renewed forms of governance in sports organizations, which affirm the implementation of this new roadmap of powers.

\section{A socio-political and typographical approach to sports organizations and methods of governance}

Analyzing sport as a social event, George Magnane (1964) emphasized very early on the risks that come from a democratic system in sports federations. From a sociopolitical perspective, the work of Jean Meynaud (1966) was published during the same period, which analyzed the link between sports and national and local public policies. Researchers gradually attempted to characterize the governance strategies in local and federal non-profit organizations by proposing typologies and frames of reference. While these multiple classifications may be abstract and imperfect constructions, they present the advantage of a simplified interpretation of organized forms of social and political structures by setting out their commonalities and their differences (Gasparini 2003). When Bernard Ramanantsoa and Catherine Thiéry-Baslé (1989) analyzed the structural and organizational types of sports federations at the end of the 1980s, they established a diagnostic for these by differentiating the technical branch, the elective branch and the administrative branch. Using the analysis model of organizations developed at HEC Paris business school that distinguishes strategy, structure, decision-making and culture, they anticipated an increased alignment of charitable organizations and businesses. Bertrand Moingeon (1991) used this same organizational frame of reference to analyze the struggle for influence in which the sports committees of the French Federation of Ice Sports (Fédération Française des Sports de Glace), especially hockey, are engaged in becoming much more professionalized than other associated disciplines. The author explains that the power dynamics evolve according to economic challenges permeating sports organizations. The use of "elective filters" and "decision-making mechanisms" (Moingeon 1991, 239) therefore makes it possible to avoid the democratic interplay to the advantage of interest groups who are looking for new powers or are concerned with preserving their positions in the organization. Charles Pigeassou (1995) was interested in the effects of changes that the professionalization of sports organizations leads to in terms of modes of operation and representation of managers. He also stated that more than $60 \%$ of respondents thought that the volunteer manager role is in the process of disappearing. Consequently, investigation into more rational operational structures is carried out to the detriment of initial goals and fundamental missions (the author refers to stagnation and the vicious circle of non-profits). Contrary to these positions of withdrawal, Emmanuel Bayle (2001) takes the example of the 1996 elections, where only 5 presidents of 29 Olympic federations and 15 of 53 non-Olympic federations changed. According to him, the role of the president reveals "strategies of 
establishment" (Bayle 2001, 346). In order to characterize the methods of governance, he reconsidered the types of strategic core that François Mayaux (1996) identified in national associations to establish in his own right four modes of "governance" in sports federations: the strong presidential type where the president has significant decisionmaking power and powers of influence, the joint presidential type (president/director tandem core) where power is shared between the president and a permanent actor who is often the national technical director, the split presidential type (alliance/fragmented core) where the president is surrounded by a team of paid directors that shares and coordinates tasks, and the managerial presidential type where the core is dominated by the administrative director and/or the technical director. On a local scale, Jean-Pierre Augustin and Alain Garrigou (1985) proposed a typology of local clubs that highlighted a hierarchy depending on their positions and political and noteworthy institutions in the local political system. Depending on the identity and cultural characteristics of managers and their local institution, Jean Dumas (1987) created a political classification for sports organizations that distinguishes between corporate clubs with strong links to a local company, community clubs that bring together keen players, influencer clubs made up of people who are also opinion leaders in the fabric of local society, and lastly, municipal clubs with close links to the municipality and its elected political leaders. William Gasparini (1996) identified the different states of the origin of sports organizations and, inspired by Max Weber (1965), studied the types of authority and power exercised by the managers of associations in Strasbourg (a non-profit authority generally of a traditional type). Influenced by the work of Pierre Chifflet (1987) Laurent Rundstadler (1999) analyzed six tennis clubs in Grenoble from three different but complementary perspectives: the systemic perspective took into account the organization's formal and informal structure, the strategic perspective considered the logic of internal actions by managers and instructors, and the interactionist perspective was inspired by Erwing Goffman and the interplay of actors (1973). By using the convention theory of Luc Boltanski and Laurent Thévenot (1991), William Gasparini (2003) highlighted the use of reasoning with regard to crowds and approximate sizes to the extent that the sports organization can be seen "as a mixed montage of plans that includes several worlds or major systems of principles" (Gasparini 2003, 64). We can also cite Benjamin Coignet (2012), who, in his doctoral thesis on sports clubs in working-class areas, drew on Akrich, Callon and Latour's actor-network theory (2006) to show how individual rational natures or "networks of actors" take part in organizations as important variables in the process of innovation.

What all these French works have in common (the list is by no means exhaustive) is that they take a typological approach to sports organizations, with the aim of defining the different modalities of internal structure, types of organized politics, strategies (whether they are for alliances, protection, acquisition or opposition), and modes of governance. However, although these interpretations classifying types of organizations are useful for summarizing the division of the sports landscape on a both organizational and political level, they have limitations, notably in terms of their approach that is judged to sometimes be too static and stereotypical. Norbert Alter (2000) explains that it is not the states as such that matter because they are static, but more the process of development between these states. However, this development process can be explained only by the actions of internal and external factors of influence, which Henry Mintzberg (1982) calls contingency factors, such as environment, age or size of the organization. 
Contingency theories attempt to avoid this obstacle by proposing a more evolutionary and dynamic interpretation of organizations, referring particularly to the idea of life cycles in organizational configurations.

\section{Contingency theories and life cycles in professional configurations}

The third axis in the development of a sociology of sports organizations is based on contingency theories that emerged in the 1970s. Giving additional momentum to studies on organizations, these management theories suggest that the evolution of organizations can be explained via the influence of environmental variables that affect them (Chappelet 2016). As Michel Foudriat (2007) highlighted, "the survival of organizations often depends on a sufficient knowledge of exchanges with their environment or at least with those that, at a given moment, have become the most restrictive or the most necessary" (Foudriat 2007, 45). These organizational approaches were developed by Joan Woodwards (1958), Paul Lawrence and Jay Lorsch (1967), in particular, and, more recently, by Henry Mintzberg (1982). Following these founding works, many researchers take care to demonstrate the forms of organizational hybridization - both bureaucratic and professional - that sports organizations can take in response to professionalization as a goal. Influenced by Henry Mintzberg's configurational models (1982), Christophe Durand (1994) created a life cycle for professional clubs. The strategic apex is made up of club presidents and paid managers whose expertise and knowledge is appreciated according to the team's results. The middle line that links the apex and the base is made up of coaches, sports directors, and commercial directors. They are intermediate managers that the author separates into administrative and technical personnel. The operating core are paid athletes or freelancers who have become "mercenaries" for the club that employs them. According to the type of external alliance (dominant, passive, and divided), the author suggests categorizing professional clubs into five configurations or internal coalitions: entrepreneurial, machine, ideological, professional, and political. He ultimately put forward a life cycle for professional sports clubs. The shape of this can vary according to the severity of internal and external political conflicts. Also referring to Mintzberg's typology of regulation mechanisms (1982), Jean Nizet and François Pichault (1995) defined four systems of influence in sports organizations: the system of personal control finds power at the strategic apex and coordinates through direct supervision; the system of specialized skills gives power to the operating core who coordinate through the standardization of qualifications; the system of bureaucratic control is based on standardization by analysts of work processes and results; the system of ideological control situates power in the ideology analysts who coordinate by standardizing norms. In an article dedicated to the process of professionalizing national sports federations, Emmanuel Bayle (2001) considers several European and Anglo-Saxon works that refer to Mintzberg's theories. All of these authors agree that major sports federations are unavoidably progressing towards the bureaucratic professional configuration. Denis Bernardeau-Moreau (2004) studied the French Federation for Equestrian Sports (Fédération Française d'Equitation) and also put forward a life cycle where the final stage is the professional configuration "where the dominating force is decentralization that advocates greater autonomy for the base, rather than the apex" (Bernardeau-Moreau 2004, 57). More recently, Thierry Zintz and Daniel Vaillaux (2008) also decided on the hybridization of sports federations, reconciling the mission-focused model with the decision-making 
weight of volunteer managers and the professional model with the managerial weight of paid managers.

Although the works on sports organizations have identified a wide variety of organizational configurations, the majority agreed on the supremacy of the most professional forms. These organizations, which are evolving in an increasingly complex environment, are characterized by a heightened formalization of their operating function, regulation mechanisms through the standardization of qualifications and results, a growing division of tasks, and capacity building. The table below reestablishes the various forms of organizational hybridization, developments, and characteristics that researchers have observed in sports organizations.

Table 1. The life cycles of the configurations of sports organizations

\begin{tabular}{lccc}
\hline & $\begin{array}{c}\text { Configuration } \\
\text { mission-focused }\end{array}$ & $\begin{array}{c}\text { Configuration } \\
\text { bureaucratic }\end{array}$ & $\begin{array}{c}\text { Configuration } \\
\text { professional }\end{array}$ \\
\hline Environment & Simple & $\begin{array}{c}\text { Complex but } \\
\text { monopolistic }\end{array}$ & $\begin{array}{c}\text { Complex and } \\
\text { competitive }\end{array}$ \\
$\begin{array}{l}\text { Formalization of operating } \\
\text { methods }\end{array}$ & Weak & Strong & Very strong \\
Mechanisms of regulation & $\begin{array}{c}\text { Standardization of } \\
\text { norms }\end{array}$ & $\begin{array}{c}\text { Standardization of } \\
\text { work processes }\end{array}$ & $\begin{array}{c}\text { Standardization of } \\
\text { qualifications and } \\
\text { results } \\
\text { Very strong }\end{array}$ \\
Division of work & Weak & Strong & $\begin{array}{c}\text { Strong } \\
\text { Skills }\end{array}$ \\
Localization of power & Weak & Average & Professional \\
& Volunteer & Administrative \\
managers & managers & Managers \\
\hline
\end{tabular}

Although this quick inventory of research work demonstrates the considerable contribution of the sociology of organizations in enabling a better understanding of sports organizations that are in the midst of change, a critical analysis must still be carried out. For decades, the sociology of organizations has, of course, provided relevant perspectives on understanding social phenomena. Its explanatory analysis is real. However, as Michel Crozier (2000) and Henri Amblard et al. (1996) note, some limitations restrict its development and prevent its spreading. From these, we shall examine the operational scope in the field of sports organizations.

\section{The opportunity for a sociological intervention in sports organizations}

Studies on sports organizations obviously could not be conducted without referring to the various organizational theories cited above. Among these, two are often used by researchers. They each present advantages, but also disadvantages. Strategic analysis makes it possible to recreate the nature of the power balances between those involved in 
sports, but its extremely conflicting and utilitarian view of individual relationships is often criticized (Reynaud 1999; Bernoux 2004; Boussard 2008). The idea, defended by the supporters of strategic analysis, that power is "a natural and inevitable manifestation of human action" (Crozier 2000, 147) cannot automatically be applied to a sports domain that is largely made up of volunteers who give their time freely to support their chosen non-profit associations. According to Mintzberg's analysis, its issue is that it is an outlook that is too close to agentic state theory (Livian 2010, 37) in the sense that it relates more to the structure than its constituent parts. In judging it to be determinist and macrosocial, some sociologists (Amblard et al. 1996, 2; Bernoux 2004, 95) criticize the organizational system without considering the actors that make it possible, running the risk of misrepresenting social reality through excessive modeling. Outside these theoretical and methodological critiques, there are others that are likely more problematic. Of course, the professionalization of sports organizations no longer seems to be in doubt, which poses the fundamental question of how adaptable the actors are to these new forms of regulations and competition. Further, faced with these deep-rooted trends that can be easily envisioned as becoming more and more pressing in the years to come, will the impact of studying the sociology of sports organizations be satisfactory? In fact, one criticism is often made in opposition to the sociology of organizations: its difficult operational scope.

This operational scope warrants examination with regard to reflexive sociology that, as closely as possible to the actor in the situation, questions and sometimes doubts the relevance and usefulness of its action. Michel Crozier (2000) distinguishes two types of knowledge and observes that the sociology of organizations "is applicable, but not usable" (Crozier 2000, 292). The author emphasizes that it certainly takes into account different situations but it struggles to demonstrate its usefulness outside of actors in research with tools and solutions in the day-to-day management of their professional situations. Rot and Segrestin (2016) highlight that the sociology of organizations has been faced from the start with the difficulty of filling the gap between the categories of analysis and action, between actual research activity and intervention activities (Rot and Segrestin 2016, 8). According to Tubiana (2017), its "supposed decline" was due in part "to its results, often deceptive, on the process of transforming administrations and major companies" (Tubiana 2017, 102). To find a solution to this operational weakness, some authors advocate a more interventionist sociological position. Hess (1981) and Savoye (1994) explain that this position has its foundations in three principal theoretical standards: clinical sociology (McClung Lee 1966; Alinsky 1978; De Gaulejac and al. 2012), psychosociology (Lewin 1944; Jacques 1951; Moreno 1953), and sociological intervention (Touraine 1990; Dubet 2001; Herreros 2008). Although these theoretical approaches differ in the concepts that they employ, they agree on their relationship with the subject. Using an empirical method and position, all are looking to provoke the group into managing themselves in order to enable them to develop autonomy and their capacity to manage their conflicts by themselves. Touraine (1978) explains that what characterizes the intervention and different types of action research is the desire to be "as close as possible to the action" (Touraine 1978, 205). Keen to take social demand into consideration and respond to it as fairly as possible, the intervention position also avoids all epistemological disruption between common sense and scientific knowledge. According to it, there is no watertight separation, but rather a continuous dialogue between the researcher and the actor enabling the production of shared knowledge. 
In adopting this interventionist position, sports sociologists are attempting to analyze organizations from a position of immersion. Zanna (2008) conducted action research among incarcerated minors for whom intense sports had a socializing and empathic effect. Lorgniers and al. (2008) carried out action research on the public management of tourism and leisure sports. Duchateau (2012) conducted a survey on young people from disadvantaged areas in order to report on how they view their health. Alternating between periods of being immersed in the situation with moments of reflection and conceptualization, Coignet (2012) used sociological intervention to analyze the number of actions taken, often confidentially, by local actors in the world of sports (volunteer managers, project sponsors, sports coaches). According to the author, it is a case of going into the field and leaving to better understand it (Coignet 2012, 77). Highlighting the ambiguity of his position in the field, he organized regular meetings with the actors in the industry "to justify cognitive gains" to his work as a researcher (Coignet 2012, 138). The following year, Bernardeau-Moreau (2013) attempted to apply sociological intervention to sports organizations. By immersing himself in the management company of an aquatic complex in the public service delegation contract, the author attempted to both describe the situation to make it clear to the actors concerned, while also putting forward a more analytical interpretation, which made it possible to lead different main players to develop long-term improvement solutions. With his continuous back and forth, the author questioned his position of objectivity and analyzed the forms of manipulation to which he was subjected by the department and employees.

Sociological intervention is a discipline in its infancy in sports organizations. However, it would gain from being more highly regarded. It would also make it possible for actors in sports to be better aware of the developments that they experience every day without always seeing or understanding them. In response to the utilitarian expectations of practitioners, interventionist sociology also constitutes an interesting research focus for the sociology of organizations, the aim of which is above all, according to Crozier, to produce "empirical knowledge of the structure and real means of regulation in the human system, which underpins a given field of action" (Crozier $2000,157)$. By prioritizing practice over theory, the sociology of organizations does not, however, dismiss the increase in generalization when opportunity allows, even if this does not constitute an end in itself, according to Crozier.

\section{Conclusion}

In 40 years of existence, the sociology of sports organizations has found its place in the field of sports sciences. However, this legitimacy is still uncertain and must be reinforced. Throughout this article, we have endeavored to better define this science, its history and its axes of reflection. We have tried to bring together all the researchers who have worked on its development and scientific recognition around coherent thematic axes. Although initially fragmented, studies on sports organizations have multiplied over recent decades, demonstrating that these organizations cannot avoid power phenomena and the problems of adapting to a changing environment any more than other social organizations. The sociology of sports organizations, like the sociology of organizations in general, is faced with scientific issues that are both theoretical and practical. Comparing their results and compiling their observations, sociologists of 
sports organizations have put forward typologies and development models for generalization purposes. The theories, frameworks, and explanatory models produced by researchers are also keys whose aim is to facilitate interpretation by actors in sports to the changes and challenges they perceive, while carrying out the difficult task of measuring the consequences in the long term. This necessary awareness - Giddens (1987) speaks of practical consciousness - concerns the day-to-day actions that lead the actors in question to adapt to the changes in sports organizations. To understand and master the changes to overcome, the actors in sports must also rise to a "discursive consciousness" (Giddens 1987) as the only option for giving them acceptable solutions in order to better manage the change. In fact, one other criticism is often made in opposition to the sociology of organizations: the fact that it does not lend itself easily to generalization. The three axes of development described in the texte are a good illustration of this criticism of the conceptualization insofar as a wide range of works on organizations, their structures, and their configurations accumulate without a clear general theory of organizations emerging that is capable of bringing together all sectors and professional fields (public, private, non-profit, and entrepreneurial organizations) and defining a collection of internal and external influence factors that are both measurable and shared by the majority of them. In a complex setting that hosts a wide and mixed variety of actors and organizations, the sociology of sports organizations struggles, in reality, to provide the scientific community with a global analytic reading of the major developments taking place in the field. It is of course the case that not all organizations become professional and no longer express an urgent requirement for skills and specialization, but it can be imagined that the growing obligation for selffinancing in an increasingly competitive market will restrict them in the short term from being able to rationalize their operation, pool their resources, and gain efficiency. However, there is a significant amount of clarification work to be done in order to define these indicators and more precisely identify their principal characteristics. This clarification work will be the focus of future work.

The sociology of sports organizations is currently empowered. Despite this, it must not withdraw into itself. It is by crossing its results with varied disciplines, such as management sciences, the sociology of work and occupations, and even clinical sociology, that its full relevancy and usefulness will be demonstrated. Lusin BaglaGökalp (1998) wrote that the objective of the sociology of organizations is to bring the ability to understand different organizations of the social world. Catherine Balle (1990) wrote that her approach depends on its ability "to reconcile the priorities of a science and the practices of action" (Balle 1990, 122). It is in this dual character that it would make sense to place its principal attractive traits and greatest originality.

\section{References}

Akrich, M., M. Callon, and B. Latour. 2006. Sociologie de la traduction [Actor-network theory]. Paris : Presses de l'Ecole des Mines de Paris, Collection Sciences Humaines.

Alinsky, S. 1978. Manuel de l'animateur social [Rules for Radicals]. Paris: Seuil. Point.

Alter, N. 2000. L'innovation ordinaire [Ordinary innovation]. Paris : PUF, Sociologies. 
Amblard, H., P. Bernoux, G. Herreros, and Y.F. Livian. 1996. Les nouvelles approches sociologiques des organisations [New approaches to the sociology of organizations]. Paris : Seuil, Sociologie.

Augustin, J.P., and A. Garrigou. 1985. Le rugby démêlé. Essai sur les associations sportives, le pouvoir et les notables [Rugby untangled: Essay on sports organizations, power and public figures]. Bordeaux : Le Mascaret.

Bagla-Gökalp, L. 1998. Sociologie des organisations [Sociology of organizations]. Paris : La Découverte, Repères.

Balle, C. 1990. Sociologie des organisations [Sociology of organizations]. 4th ed. Paris : PUF, Que sais-je ? [2499].

Barget, E., and D. Vailleau. dir. 2008. Management du sport. Théories et pratiques [Sports management: Theories and practices]. Brussels : De Boeck. 75-110.

Bayle, E. 1999. Management et performance des organisations à but non lucratif ; le cas des fédérations sportives nationales [Management and performance of non-profit organizations ; the case of national sports federations], Thèse de Doctorat : Sciences de Gestion, Limoges,

Bayle, E. 2001. Le processus de professionnalisation des fédérations sportives nationales [The process of professionalization in national sports federations]. In P. Chantelat, La professionnalisation des organisations sportives, nouveaux enjeux, nouveaux débats [The professionalization of sports organizations, new challenges, new debates]. Paris : L'Harmattan. Espaces et temps du sport.

Bernardeau-Moreau, D. 2004. Sociologie des fédérations sportives. La professionnalisation des dirigeants bénévoles [Sociology of sports federations. The professionalization of volunteer managers]. Paris : L'Harmattan, Logiques sociales.

Bernardeau-Moreau, D., F. Grima, and P. Paillé. 2012. "Créer du consensus dans un partenariat public/privé : analyse des compromis et arrangements managériaux [Creating a consensus in a public-private partnership : analysis of compromise and managerial arrangements]". In C. Desmarais. La transformation des organisations publiques [The transformation of public organizations]. Management international $16(3): 38-49$.

Bernardeau-Moreau, D. 2013. La sociologie d'intervention. Le sociologue au cour des organisations associatives, sportives et de loisirs [Sociological intervention. Sociology at the heart of non-profit, sports and leisure organizations]. Paris : L'Harmattan, Logiques sociales.

Bernoux, P. 1985. La sociologie des organisations [The sociology of organizations]. Paris : Seuil.

Bernoux, P. 2004. Sociologie du changement dans les entreprises et les organisations [Sociology of change in companies and organizations]. Paris : Points, Essai.

Boltanski, L., and L. Thévenot. 1991. De la justification. Les économies de la grandeur [On Justification. The Economies of Worth]. Paris : Gallimard, NRF essais.

Bouet, M. 1968. La signification du sport [The significance of sport]. Paris : Ed universitaires.

Boussard, V. 2008. Sociologie de la gestion : les faiseurs de performance [Sociology of management: the creators of the performance]. Paris : Belin.

Brohm, J.M. 1976. Sociologie politique du sport [Political sociology of sport]. Nancy : Presses universitaires de Nancy.

Callède, J.P. 1988. "Collectivités locales et usagers, contribution à une analyse sociologique de l'organisation communale du phénomène sportif [Local authorities 
and use, contribution to a sociological analysis of the communal organization of sports phenomena]". In Les cahiers. (24). Actes des quatrièmes rencontres d'Angers. 26-27 November 1987. CNFPT February.

Callède, J.P. 2007. La Sociologie française et la pratique sportive [1875-2005] [French sociology and sports practice [1875-2005]. Pessac : Ed MSHA.

Callède, J.P. 2010. "La sociologie française et le sport [French sociology and sport]". La revue pour l'histoire du CNRS [Online], 26 | 2010, published online on 24 February 2013, accessed 17 March 2017. URL: http://histoirecnrs. revues.org/9262. doi: 10.4000/histoire-cnrs.9262.

Chantelat, P. (texts compiled and presented by). 2001. La professionnalisation des organisations sportives, nouveaux enjeux, nouveaux débats [The professionalization of sports organizations, new challenges, new debates]. Paris : L'Harmattan, Espaces et temps du sport.

Chappelet, J.-L. 2016, "From Olympic administration to Olympic governance". Sport in Society 19 (6) : 739-751.

Chifflet, P. 1987. Les fédérations sportives, politiques et stratégies [Sports federations, policies and strategies]. In B. Michon (dir). Sciences sociales et sports. Etats et perspectives [Social and sports sciences: states and perspectives]. Seminar titles in Strasbourg from 13 and 14 November. USHS. Laboratoire APS et sciences sociales.

Coignet, B. 2012. "L'innovation sociale et les organisations sportives associatives : le cas des clubs sportifs dans les quartiers populaires [Social innovation and non-profit sports organizations: the case of sports clubs in working-class areas]". Sociologie. University of Franche-Comté. French. <NNT: 2012BESA1003>. <tel-01320976>

Crozier, M., and E. Friedberg. 1977. L'acteur et le système [Actors and Systems]. Paris : Seuil, Points.

Crozier, M. 2000. A quoi sert la sociologie des organisations ? Théorie, culture et société [What is the purpose of organizational sociology? Theory, culture and society]. tome 1. Paris : Arslan.

Dubet, F. 2001. Plaidoyer pour l'intervention sociologique [Appealing for sociological intervention]. In D. Vrancken et O. Kuty, 2001. La sociologie et l'intervention. Enjeux et perspectives [Sociology and intervention. Challenges and perspectives]. Paris : De Boeck Université. Ouvertures sociologiques. 89-110.

Duchateau, G. 2012. "Les conceptions de la santé chez des collégiens issus de quartiers défavorisés [Understanding of health in high school pupils from disadvantaged areas]". STAPS 2 (96-97) : 85-101.

Dumas, J. 1987. "Institution sportive et jeu de pouvoir [Sports institution and power play]". In Actes des Premières Journées d'Étude de Bordeaux, Sport et changement sociale. Bordeaux : MSHA. 171-178.

Dumazedier, J. [1962] 1972. Vers une civilisation du loisir? [Towards a civilization of leisure?]. Paris : Ed du Seuil.

Durand, C. 1994. "Essai d'analyse structurelle et de diagnostic des clubs sportifs professionnels [Essay on structural analysis and diagnostic of professional sports clubs] ". PhD Sciences de Gestion. University of Caen.

Foudriat, M. 2007. Sociologie des organisations. La pratique du raisonnement [Sociology of organizations. Practical reasoning]. Paris : Pearson Éducation.

Friedberg, E. 1993. Le Pouvoir et la Règle. Dynamiques de l'action organisée [Local Orders: Dynamics of Organized Action]. Paris : Seuil. 
Gasparini, W. 1996. "Enjeux de l'engagement associatif. Contribution à une sociologie de l'organisation sportive locale [Challenges of voluntary commitment. Contribution to sociology of a local sports organization]". $\mathrm{PhD}$ Sociologie. University of Strasbourg.

Gasparini, W., and L. Scheeck. 1999. "Organiser le changement dans un service municipal des sports [Organizing change in a municipal sports service]". Revue européenne de management du sport 2 : 77-105.

Gasparini, W. 2000. Sociologie de l'organisation sportive [Sociology of sports organizations], Paris : La découverte, Repères.

Gasparini, W. 2003. L'organisation sportive [Sports organizations]. Paris : Ed Revue EPS.

Gaulejac (de), V., F. Hanique, and P. Roche. 2012. La Sociologie clinique. Enjeux théoriques et méthodologiques [Clinical sociology. Theoretical and methodological challenges]. Paris : Eres, Sociologie clinique.

Giddens, A. 1987. La constitution de la société [The Constitution of Society]. Paris : Presses Universitaires de France, Sociologies.

Goffman, E. 1973. The presentation of self in everyday life. London: Penguin.

Herreros, G. 2008. Au-delà de la sociologie des organisations. Sciences sociales et intervention [Beyond the sociology of organizations. Social sciences and intervention]. Paris : Erès, Sociologie économique.

Hess, R. 1981. La Sociologie d'intervention [The sociology of intervention]. Paris : Presses Universitaires de France, Le sociologue.

Ion, J. 2001. Clubs d'athlétisme et professionalisation. Une étude de cas [Athletics clubs and professionalization. A case study]. In P. Chantelat, La professionnalisation des organisations sportives, nouveaux enjeux, nouveaux débats [The professionalization of sports organizations, new challenges, new debates]. Paris : L'Harmattan, Espaces et temps du sport : 241-254.

Iribane (d'), P. 1989. La logique de l'honneur. Gestion des entreprises et traditions nationales [The logic of honor. Managing companies and national traditions]. Paris : Seuils Points, Essais.

Jacques, E. 1951. The changing culture of a factory. Londres: Tavistock.

Lafaye, C. 1996. Sociologie des organisations [Sociology of organizations]. Paris : Nathan, 128 Sociologie.

Lawrence, P.R., and J.W. Lorsch. 1967. Organization and Environment: Managing Differentiation and Integration. Boston: Harvard University.

Lewin, K. 1944. "Dynamics of group action". Educational Leadership (I): 195-200.

Livian, Y.F. 2010. Introduction à l'analyse des organisations [Introduction to the analysis of organizations]. Paris : Economica.

Loirand, G. 2001. Le bénévolat sportif : les ambiguïtés d'un engagement [Sports volunteers: The ambiguities of commitment]. In P. Chantelat, La professionnalisation des organisations sportives, nouveaux enjeux, nouveaux débats [The professionalization of sports organizations, new challenges, new debates]. Paris : L'Harmattan, Espaces et temps du sport : 273-300.

Loret, A. Ed. [1993] 1995. Sport et Management, De l'éthique à la pratique [Sport and management, from ethics to practice]. Paris : Dunod, Ed EPS.

Lorgnier, N. et al. 2008. "Réflexion sur la gestion publique du tourisme et des loisirs sportifs de nature. L'exemple de l'offre sur le territoire du Syndicat Mixte de la Côte d'Opale [Reflection on public management of tourism and outdoor leisure sports. 
Example of the offer in the area of the "Syndicat Mixte" of the Opal Coast]". Staps 2 (80) : 33-37.

Magnane, G. 1964. Sociologie du sport. Situation du loisir sportif dans la culture contemporaine [Sport sociology. The position of leisure sports in contemporary culture]. Paris : Gallimard.

Malenfant. C. 1988. Les territoires de pratiques. Espaces régionaux et motivations du travail volontaire dans les associations sportives en France [Regions of practices. Regional spaces and motivations for voluntary work in sports associations in France]. Les politiques municipales des sports. Actes des quatrièmes rencontres d'Angers. 26-27 November 1987. Les cahiers (24).

Mayaux, F. 1996. "Noyau stratégique des associations : quel partage des pouvoirs entre dirigeants bénévoles et dirigeants salariés? [Strategic core of associations: how are powers shared between volunteer and paid managers?]". PhD Sciences de Gestion. University of Lyon.

McClung Lee, A. 1966. Multivalent Man. New York: George Braziller.

Meynaud, J. 1966. Sport et Politique [Sports and politics]. Paris : Payot.

Mintzberg, H. 1982. Structure et dynamique des organisations [The Structuring of Organizations]. Paris : Éditions d'Organisation.

Moingeon, B. 1991. "Contribution à une socio-économie des organisations : l'exemple d'un univers associatif [Contribution to a socio-economy of organizations: the example of a non-profit sphere]". PhD Sociologie. University of Besançon.

Moreno, J.L. 1953. Who Shall Survive? A New Approach to the Problem of Human Interrelations, NY: Beacon House.

Mounet, J.P., and P. Chifflet. 1993. "La réalisation d'un stade nautique intercommunal. Politiques sportives et stratégies fédérales [The establishment of an inter-community aquatic center. Sports policies and federal strategies]". STAPS 32 : 87-102.

Nizet, J., and F. Pichault. 1995. Comprendre les organisations, Mintzberg à l'épreuve des faits [Understanding organizations, Mintzberg put to the test]. Paris : Ed G. Morin.

Noé, N. 1989. "Politique sportive municipale : analyse socio-politique du jeu des acteurs et de leur adaptation à l'évolution des pratiques [Municipal sports policy: a socio-political analysis of the interplay of actors and their adapting to the development of practices]". Essay for DEA STAPS. University of Paris-Sud Orsay.

Offerlé, M. 1998. Sociologie des groupes d'intérêts [Sociology of interest groups]. 2th ed. Paris : Ed Montchrestien.

Pigeassou, C. 1995. "Le management du sport associatif : les enjeux du futur [Managing non-profit sports: challenges of the future]". Sport et culture $1: 56-69$.

Pociello, C. 1999. Sports et sciences sociales [Sports and social sciences]. Paris : Vigot, Repères en éducation physique et en sport.

Ramanantsoa, B., and C. Thiéry-Baslé. 1989. Organisations et fédérations sportives. Sociologie et management [Organizations and sports federations. Sociology and management]. Paris : Presses Universitaires de France, Pratiques corporelles.

Reynaud, J.D. 1997. Les règles du jeu. L'action collective et la régulation sociale [The rules of the game. Collective action and social regulation]. 3th ed. Paris : Armand Colin, Collection U.

Reynaud, J.D. 1999. Le conflit, la négociation et la règle [Conflict, negotiation and the rules]. Toulouse : Octarès. 
Richet, C. and B. Soulé. 2007. "La gestion déléguée d'un complexe aquatique de sportloisirs : Le service public à l'épreuve de stratégies particularistes [Delegated management in a sports leisure aquatic complex: public services tested by particularist strategies]". Gérer et Comprendre. Annales des Mines 87 : 12-22.

Ringuet-Riot, C. et al. 2014. "Volunteers roles, involvement and commitment in voluntary sport organizations: evidence of core and peripheral volunteers". Sport in Society 17 (1) : 116-133.

Rot, G., and D. Segrestin. 2016. "La sociologie des organisations : cheminements et situation présente [The sociology of organizations: developments and the current situation]". Entreprises et histoire 3 (84) : 5-10.

Rundstadler, L. 1999. "Stratégies et jeux d'acteurs de l'offre locale en tennis [Strategies and interplay between actors in the local tennis club]". PhD Sciences biologiques. University of Grenoble.

Sainsaulieu, R. 1987. Sociologie de l'organisation et de l'entreprise [Sociology of organizations and companies]. Paris : Presses de la FNSP/Dalloz.

Savoye, A. 1994. Les Débuts de la sociologie empirique [The origins of empirical sociology]. Paris : Meridien Klincksieck.

Stumpp, S., and W. Gasparini. 2003. "Les conditions sociales d'émergence du volleyball professionnel. De l'espace national au club local [1970-1987] [The social conditions of the emergence of professional volleyball. From a national stage to a local club [1970-1987]". STAPS 1 (63) : 123-138.

Suaud, C. 1996. Le sport dans tous ses pouvoirs [Sport in all its capabilities]. L'espace des pouvoirs du sport. Les cahiers de l'Université sportive d'été. Ed MSHA.

Taylor, F.W. 1911. The principles of scientific management, New York: Harper.

Touraine A., 1978. La Voix et le Regard : sociologie des mouvements sociaux [The Voice and the Expression: the sociology of social movements]. Paris : Seuil.

Touraine, A. 1990. Production de la société [The production of society]. Paris : Seuil, Sociologie.

Tubiana, J. 2017. "Jubilé de la sociologie des organisations : un numéro spécial de la revue Entreprises et Histoire [The anniversary of the sociology of organization: a special issue of the revue Entreprise et Histoire]". Gérer et comprendre 4 (130) : 101-103.

Viallon, R., and P. Chantelat. 2001. La logique du management associatif : le cas du Grenoble Université Ski [The logic of non-profit management: the case of the University of Grenoble Ski Club]. In P. Chantelat, La professionnalisation des organisations sportives, nouveaux enjeux, nouveaux débats [The professionalization of sports organizations, new challenges, new debates]. Paris : L'Harmattan. Espaces et temps du sport : 107-111.

Walter, E., and M. Falcoz. 2007. "Travailler dans un monde de bénévoles : contraintes et limites de la professionnalisation dans les clubs sportifs [Working in a world of volunteers : restrictions and limitations of professionalization in sports clubs]". Revue des études coopératives, mutualistes et associatives 306 : 78-91.

Weber, M. 1965. Essais sur la théorie de la science. [Essay on the theory of science] Paris : Plon.

Woodward, J., 1958. Management and Technology. London: Her Majesty's Stationary Office.

Yerles, M. 1984. "Stratégies des dirigeants dans les fédérations françaises et québécoises de sport amateur [Management strategies in French and Quebecois 
amateur sports federations]". Sport et sociétés contemporaines. Société française de sociologie du sport.

Zanna, O. 2008. "L'expérience partagée de la douleur physique peut-elle être socialisante? [Could the shared experience of physical pain be a socializing factor?]". STAPS 1 (79) : 95-111.

Zintz, T., and D. Vailleau. 2008. "La gouvernance des fédérations sportives. Proposition d'un cadre d'analyse et d'action [Governance of sports federations. Proposition for an analysis and action framework]". Revue française de gestion 187 : 15-35. 